\title{
ОБГРУНТУВАННЯ ВИМОГ РОЗВИТКУ РЕКРЕАЦЇ̈ ГІРСЬКИХ РАЙОНІВ ІВАНО-ФРАНКІВСЬКОЇ ОБЛАСТІ В КОНТЕКСТІ ЕКОЛОГІЧНОЇ БЕЗПЕКИ
}

Створення рекреаційних інфраструктури в Карпатському регіоні в період з 2000 року зазнало ряд змін, що відбувалися в соціально-економічній, політичній, демографічній, геополітичній та інших сферах. Вони ставлять нові вимоги до створення об'єктів сучасної рекреації. Першочергову роль у рекреаційному освоєнні гірських районів Івано-Франківської області належить врахування вимог екологічності, як базисного елемента збереження середовища для розвитку рекреації.

У попередніх дослідженнях проаналізовано та оцінено потенціал незадіяних рекреаційних ресурсів регіону та охарактеризовано особливості та чинники архітектурно-планувальної організації. Виділені чинники формування рекреаційної сфери поділяються на п’ять груп: соціальні; економічні; демографічні; політичні; екологічні; ті, що належать до матеріальної та духовної культури населення.

У дослідженні обгрунтовано такі вимоги екологічної безпеки розвитку рекреації в гірських районах Івано-Франківської області: вимога відповідності стратегіям та планам регіонального розвитку, яка передбачає врахування та узгодження стратегій та програм збереження підвищення екологічної безпеки на всіх рівнях рекреаційного районування та проектування; поглиблення наукової обгрунтованості проектних рішень 3 урахування даних екологічного моніторингу, соціальної орієнтованості архітектурних рішень при формуванні рекреаційного середовища, що передбачає зміну систем громадських обговорень та роботи з територіальними громадами, енергоефективності та екологічності проектованих об'єктів, що передбачає використання альтернативних джерел енергії, енергоощадних матеріалів та конструкцій, а також екологічної безпеки проектних рішень.

Ключові слова: екологічна безпека регіону, об'єкти рекреації, гірські населені пункти Івано-Франківської області, вимоги розвитку рекреації.

Постановка проблеми. Поряд з основними проблемами гірських населених пунктів ІваноФранківської області: низька народжуваність, міграційні процеси та проблеми якості життя місцевого населення в останнє десятиліття особливо гостро постала проблема неправильного освоєння рекреаційних ареалів, що знижують показники екологічності а подекуди призводять до екологічного колапсу. Вирішення цієї проблеми в архітектурно-містобудівній галузі можливе шляхом включення нових вимог та принципів розвитку рекреації, що враховують умови розвитку екосистеми окремих територій та їхній рекреаційний потенціал.

Аналіз останніх досліджень і публікацій. У науковій літературі багато авторів займаються різними аспектами екологічних проблем регіону. проблеми екологічної безпеки та шляхи їхнього вирішення висвітлені в працях В.Н. Шмандія [2], О. В. Харламова [2], А. А. Гаврілідіса [3], В. С. Колесника [1]; дослідження екологічної ситуації в контексту гірських та передгірських населених пунктів займались О. Бондарчук [4], О. С. Глух [5], В. О. Фесюк [6] та інші; проблему природокористування та моніторингу екологічної ситуації в Карпатському регіоні досліджували О. М. Мандрик [9], Л. М. Архипова [9], О. В. Побігун [9], О. Р. Манюк [9].

Із закордонних дослідників проблеми енергозбереження та сталого розвитку населених пунктів у своїх працях висвітлювали Milan Kumar Jana [7], Adam James [12] та інші.

Проте в цьому дослідженні сформовані вимоги екологічної безпеки на окремих ареалах у контексті архітектурного освоєння та розвитку інфраструктури рекреації. На нашу думку зосередивши дослідження саме на стадії первинного розвитку інфраструктури, через містобудівну та проектну документацію дозволить не допустити негативних впливів на екосистему та зберегти баланс у природокористуванні та збереженні екологічної привабливості Карпат.

Метою роботи $\epsilon$ обгрунтування вимог розвитку рекреації при архітектурно-містобудівному освоєнні території.

Виходячи зі сформульованої мети, окреслено завдання: 
- провівши передній аналіз рекреаційного потенціалу регіону, виділити чинники впливу на архітектурну організацію та розвиток рекреації на теренах Карпатського регіону; області;

- обгрунтувати вимоги розвитку рекреації в гірських населених пунктах Івано-Франківської

- визначити умови дії цих вимог та шляхи їхнього реалізування;

- сформувати практичні рекомендації дії вимог розвитку рекреації в гірських населених пунктах Івано-Франківської області.

Виклад основного матеріалу. Створення рекреаційних інфраструктури в Карпатському регіоні в період з 1991 року зазнало ряд змін, що відбувалися в соціально-економічній, політичній, демографічній та геополітичній та інших сферах. Вони ставлять нові вимоги до збереження екосистеми регіону. Проаналізувавши та оцінивши потенціал незадіяних рекреаційних ресурсів регіону, охарактеризувавши особливості та чинники архітектурно-планувальної організації і розвитку об'єктів сучасної рекреації, виділяємо наступний ряд вимог, виконання яких дозволить створити дієву інфраструктуру рекреації.

У попередніх дослідженнях проаналізовано та оцінено потенціал незадіяних рекреаційних ресурсів регіону та охарактеризовано особливості архітектурно-планувальної організації 150 об’єктів сучасної рекреації. На основі отриманих даних сформовано чинники розвитку рекреації в Карпатському регіоні. Виділені чинники формування рекреаційної сфери поділяються на п'ять груп: соціальні; економічні; демографічні; політичні; екологічні; ті що належать до матеріальної та духовної культури населення.

Виконання вимог відповідності стратегіям і планам регіонального розвитку передбачає врахування та узгодження стратегій, програм та планів розвитку регіону на всіх рівнях рекреаційного районування та архітектурної діяльності. Інструментом реалізування стратегії розвитку рекреації, що розрахована на періоди від $2-5$ років, $\epsilon$ програми розвитку адміністративних районів, окремих населених пунктів. Вони дозволяють локально коригувати окреслені межі розвитку території, реорганізацію сфери послуг, створення додаткової інфраструктури рекреації в короткотривалому періоді (місяць, квартал, півріччя, рік). Метою програм розвитку є забезпечення комплексного вирішення основних завдань та проблем розвитку на різних рівнях районування, покращити якість сервісу, вказати вектор розвитку інфраструктури рекреації. Реалізування програми розвитку рекреації передбачає виконання комплексу організаційних, управлінських, соціально-економічних, нормативних, екологічних, господарських заходів всіх сфер господарювання. Відсутні програми та стратегії розвитку території для окремих ділянок, як наслідок відбувається несистемне розміщення об'єктів рекреацію на території регіону. Практика архітектурно-планувальної організації об'єктів рекреації в Коломийському районі показала невідповідності між проектними рішеннями та розробленою програмою розвитку району на 2016-2020 роки. При цьому програми та плани розвитку території мають передбачати не лише декларативну форму основних аспектів розвитку рекреації, але й зазначати механізми їхнього реалізування. Це дозволить на рівні районних та обласних рад формувати структуру розвитку адміністративних районів 3 окресленими пропозиціями будівництва та рекреаційного профілю об'єктів сучасної рекреації, їхніх потужностей та виділення ділянок реалізації. Також у межах дії цих програм слід створити спрощений механізм їхньої майнової участі та оформлення дозвільної документації.

Саме цей шлях дозволить створити прозору програму розвитку рекреації та підвищити його інвестиційну привабливість. Виникає потреба оновлення та регулювання системи забудови населених пунктів через створення дієвих генеральних планів території (на сьогодні тільки 35\% території регіону мають оновлену містобудівну документацію, що регулює існуючі зони забудови, без чітких прогностичних пропозицій розвитку). Саме на цьому рівні слід провести реформування підходів до співпраці з місцевим населенням, інвесторами, органами влади. На нашу думку, програми розвитку рекреації в регіоні слід формувати на основі виділення незадіяного рекреаційного потенціал регіону та розвитку на його основі сучасних видів рекреації. Розроблені стратегії розвитку рекреації в адміністративних районах підкреслюють пріоритетність цієї галузі в економіці Карпатського регіону та формують курс практичних кроків на різних рівнях державної влади. Швидке освоєння рекреаційного потенціалу 3 орієнтацією на сучасні види рекреації викличе зміни в інших галузях господарства регіону та створить умови для вирішення наявних проблем краю (безробіття, міграція трудових ресурсів, низький рівень життя місцевого населення). Разом із цим відбувається реорганізація економіки регіону, що функціонуватиме 
ринковому середовищі, а геополітичний потенціал окремих адміністративних районів (Верховинського, Надвірнянського, Коломийського) дозволить сприяти міжнародним інвестиціям та розвитку регіону.

Проведений аналіз реалізованих об'єктів сучасної рекреації та наявного рекреаційного потенціалу на території дослідження свідчить про потребу формування вимоги поглиблення наукової обгрунтованості проектних рішень з урахування даних екологічного моніторингу. Вона передбачає активізацію наукових досліджень регіону, проведення класифікації та систематизації об'єктів сучасної рекреації, обгрунтування особливостей їхнього формування, структурних та функціональних зв'язків в тому числі і ширшим використанням світового досвіду проектування та функціонування рекреаційних об’єктів. Існує потреба постійного моніторингу процесів в екологічній, господарській, економічній, соціальних сферах регіону. Дані дослідження можуть вестися, як на базі сформованих центрів дослідження рекреації (центр розвитку рекреації «Косів'янка» в м. Косів), так і новостворених осередків моніторингу рекреації. Ця вимога поширюється на всі етапи проектування. Особливу увагу слід приділити розробленню проектних завдань, які повинні мати наукове обгрунтування. В умовах процесу адміністративнотериторіальної реформи існує потреба проведення досліджень та вивчення рекреаційного потенціалу, шляхів його залучення в рекреацію. На нашу думку, доцільним є створення на базі даних громадських центрів, інстанцій, основними завданнями яких є:

- ведення моніторингу процесів, що відбуваються в регіоні;

- здійснення оцінки змін, що відбувають в сфері відпочинку;

- здійснення наукового обгрунтування для проектних завдань формування сучасної рекреації;

- брати участь у розробленні проектних пропозицій формування об'єктів сучасної рекреації;

- брати участь в експертуванні проектних пропозицій з позиції впливу нових об’єктів на екологічний, економічний, соціальний стан регіону.

Слід створити розвинуту ієрархію служб моніторингу. Першою їхньою групою виступають селищні територіальні громади, на базі яких збиратимуть інформацію про ситуацію на місцях.

Наукове обгрунтування проектних рішень виконує ряд завдань на етапі до проектних пропозицій та формує рекомендації, що дозволяють підвищити ефективність та раціональність використання наявного рекреаційного потенціалу, створити архітектурно-планувальні вирішення, що відповідають вимогам часу та кон'юктури ринку. При цьому, ще до стадії реалізації проекту можна отримати показники ефективності використання даного проекту, доцільність його спорудження, функціонування в реальних умовах та ефект його реалізування для окремо взятого населеного пункту, району, області (рис. 1).

Виконання вимоги наукового обгрунтування проектних рішень дасть можливість вказати шляхи створення більш ефективних та дієвих об’ємно-планувальних вирішень. Також ця вимога забезпечує зв’язок об'єкта сучасної рекреації в системі «об'єкт - об'єкт, об'єкт - рекреаційний вузол, об'єкт - рекреаційний район, об'єкт - рекреаційний регіон, об'єкт - навколишнє середовище, об’єкт - система забудови».

Стратегія розвитку рекреації в Карпатському регіоні передбачає як реорганізацію наявної матеріально-технічної бази з урахуванням вимог сучасної рекреації, так і створення додаткової інфраструктури (прокладання автошляхів, формування об'єктів сучасної рекреації). При цьому загосподарювання додаткових ареалів відбуватиметься в системі сформованого адміністративнотериторіального устрою. В Україні взято курс на реформу місцевого самоврядування з наданням більших повноважень та фінансових ініціатив територіальним громадам. Постає вимога соціальної орієнтованості архітектурних рішень при формуванні рекреаційного середовища. Вимога громадського обговорення проектних рішень є законодавчо підтримана. Проте ця вимога вказує на зміну форми участі громади не тільки як погоджувального органу на останніх етапах представлення проекту, але й як тісної співпраці населення 3 інвесторами на всіх стадіях проектування. Тим самим існування конфліктів на останніх етапах реалізування об'єкта немає. Вимога соціальної орієнтованості проектних рішень дозволяє вирішити такі завдання:

- забезпечує контроль громади процесу проектування рекреаційного об’єкта через багаторівневе обговореннях проектних рішень;

- дозволяє створити ідею, що максимально повно враховуватиме як думку спеціалістів, так і місцевого населення; 
- дає можливість отримання важливої інформації та ідей від місцевого населення; рекреації.

- унеможливлює конфліктні ситуації та спротив громади реалізації об’єктів сучасної

У ширшому контексті ця вимога передбачає громадські обговорення та затвердження стратегії розвитку населених пунктів, розміщення об' єктів рекреації на цих території, визначення їхньої потужності та особливостей розвитку інфраструктури.

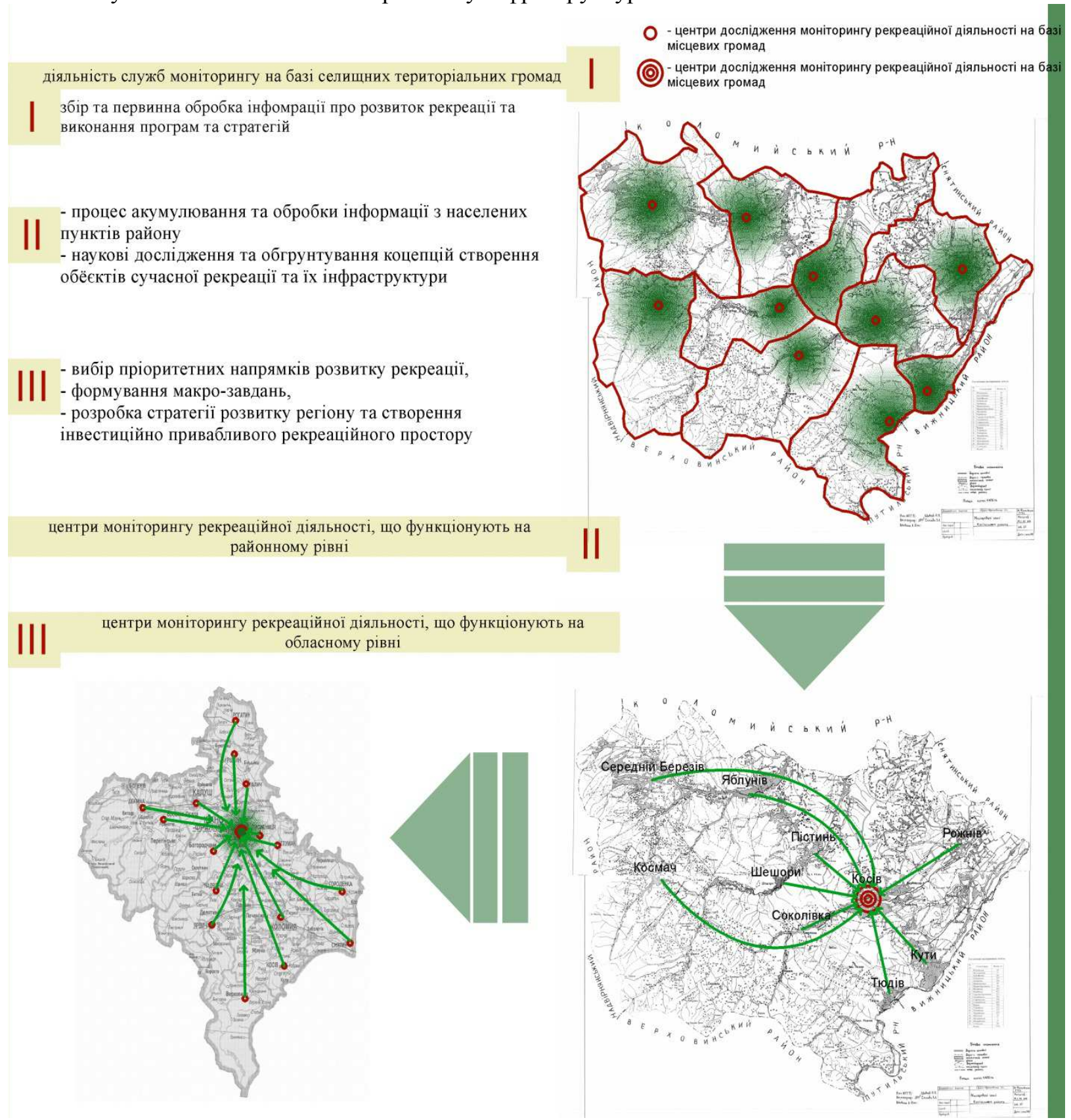

Рис. 1. Схема дії вимоги поглиблення наукової обгрунтованості проектних рішень з урахування даних екологічного моніторингу

В останне десятиліття серед основних проблем розвитку регіону постають екологічні проблеми пов'язані 3 безсистемним загосподарюванням окремих ділянок, надлишковим використанням рекреаційних ресурсів, вирубкою лісів та забруднення гірських річок. Серед вимог, інтенсивно враховуваних при формуванні рекреаційної інфраструктури в період $32000-\mathrm{x}$ років є вимога енергоефективності та екологічності проектованих об' єктів. Будь-яке будівництво передбачає зміни природнього середовища. При цьому зміни сформованого природнього середовища та подальше використання рекреаційних ресурсів довколишніх ареалів мають відбуватися з урахуванням можливостей окремого природного кластера. На території регіону існує потреба створення розгалуженої інженерної мережі, що включатиме систему каналізації та 
очищення, сміттєпереробних підприємств, підприємств сортування та вторинної переробки відходів. Відсутність таких об'єктів на території Косівського та Коломийського районів створює передумови для екологічного колапсу. При цьому недостатня потужність інженерних мереж для потреб місцевих жителів унеможливлює створення додаткових об'єктів сучасної рекреації та збільшення їхньої рекрекреаційної ємності. Створення рекреаційних об'єктів часто відбувається за залишковим принципом, де задекларовані вимоги екологічності не реалізуються. Першочерговим завданням розвитку інфраструктури рекреації є створення мережі інженерних комунікацій, які б формувалися за прогностичними моделями кількості рекреаційних об'єктів у регіоні.
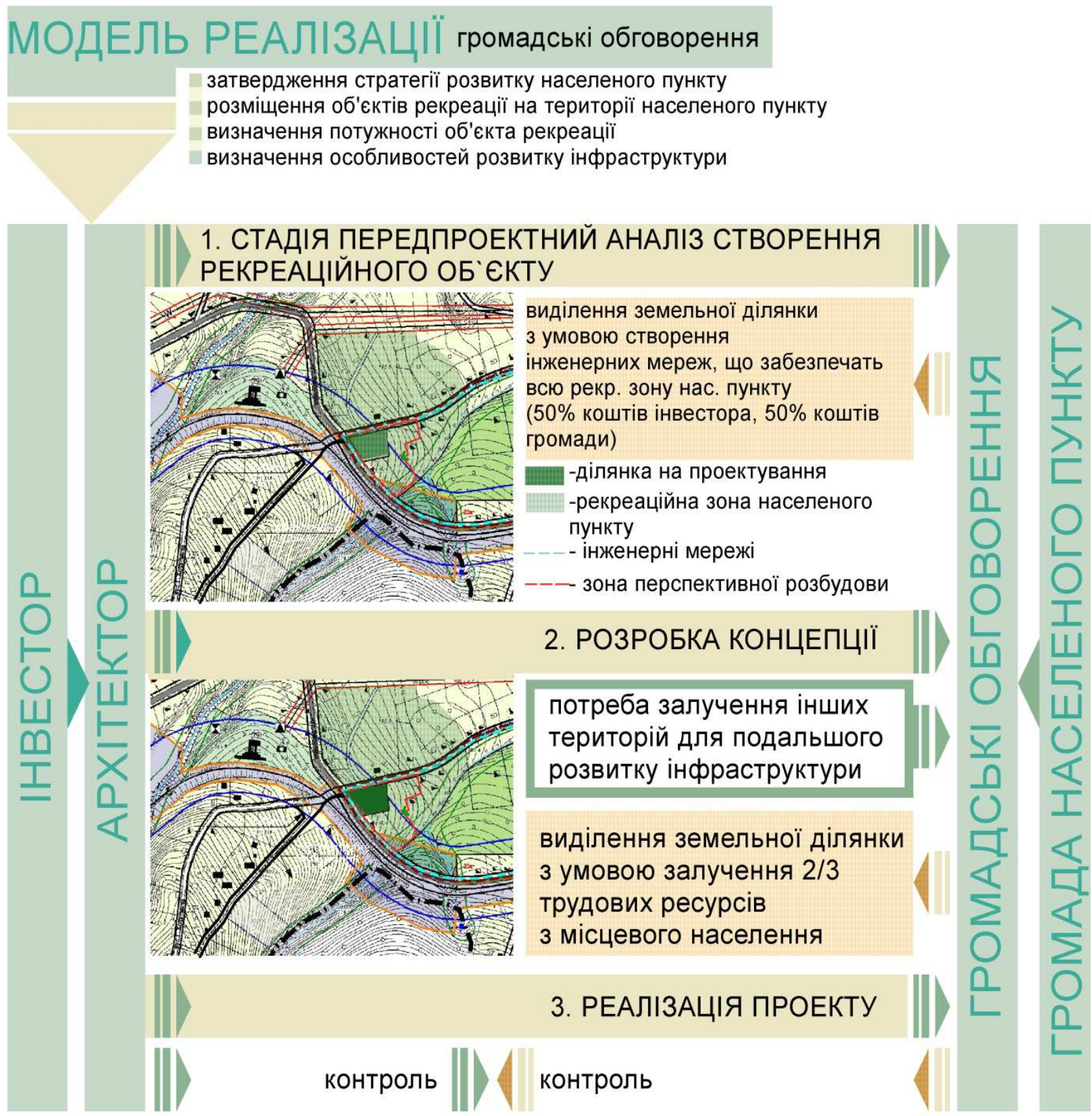

\section{Рис. 2. Схема реалізації вимоги соціальної оріснтованості архітектурних рішень при} формуванні рекреаційного середовища

Іншим завданням даної вимоги $є$ вирішення проблеми сміттєзбирання, переробки та утилізації. На даний час проблема носить загрозливий характер для екосистеми Карпатського регіону. Вісімдесят п’ять відсотків території високогір'я Карпат займають заповідники та національні парки. При цьому формування гідрологічної мережі регіону формується саме на цьому ареалі. Тому слід знайти механізми утилізації відходів у передгірській та низинній частині. На сьогодні наявна проблема спротиву місцевого населення щодо формування сміттєзвалищ на території їхніх населених пунктів. 


\section{МОДЕЛЬ РЕАЛІЗАЦІЇ ВИМОГИ ЕКОЛОГІЧНОСТІ ПРОЕКТНИХ РІШЕНЬ}

№1

\section{ВИЗНАЧЕННЯ РІЧНИХ ОБ'ЄМІВ ПОБУТОВИХ ВІДХОДІВ ТА ПЕРСПКТИВ ЇХ ЗБІЛЬШЕННЯ}

ІЕРАРХІЯ ПРІОРИТЕТІВ ПОВОДЖЕННЯ З ВІДХОДАМИ

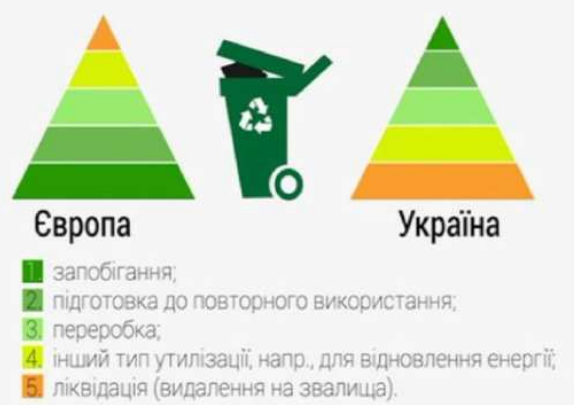

№2

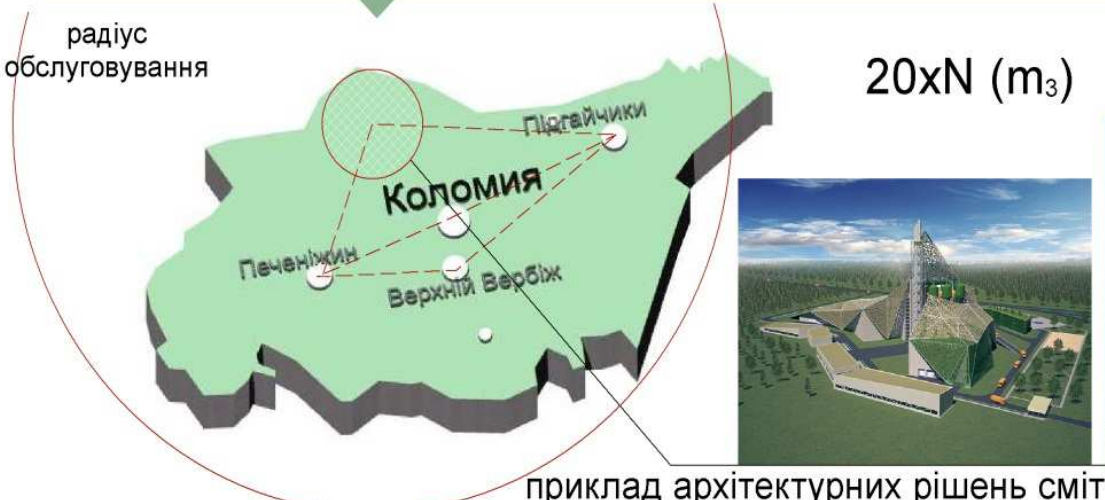

приклад архітектурних рішень сміттєпереробних підприємств
№3

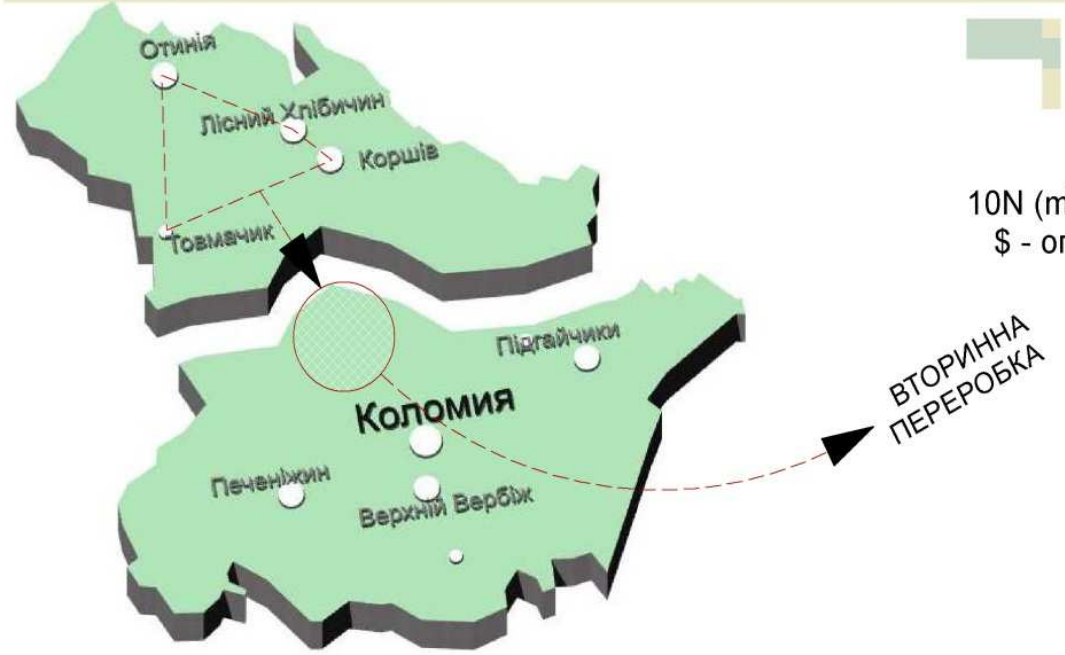

ПОШУК IHВЕСТОРIВ

ЗАЛУЧЕННЯ ДОДАТКОВИХ КОШТІВ

N $\left(\mathrm{m}^{3}\right)$ - частка сміття з інших громад

- оплата за утилізацію

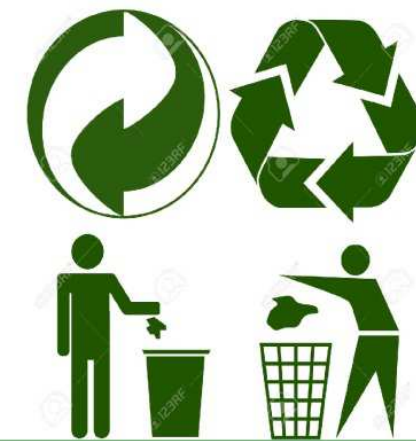

Рис. 3. Схема дії вимоги енергоефективності та екологічності проектованих об'сктів на прикладі території Коломийського району 


\section{УМОВИ СТВОРЕННЯ ОБ'ЄКТІВ СУЧАСНОÏ РЕКРЕАЦІЇ ВИМОГАМИ ЕНЕРГОЕФЕКТИВНОСТІ}

\section{№1}

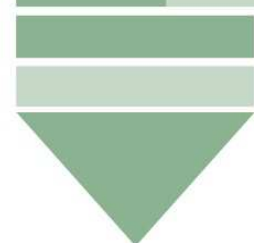

№2

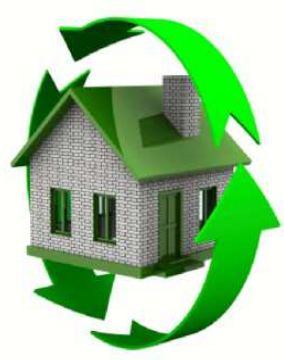

ВИКОРИСТАННЯ ЕНЕРГОЕФЕКТИВНИХ МАТЕРІАЛІВ

ПОШУК АЛЬТЕРНАТИВНИХ ДЖЕРЕЛ ЕНЕРГІЇ ТА ВЛАШТУВАННЯ ТЕХНОЛОГІЙ КОНТРОЛЮ ВИТРАТ ЕНЕРГІЇ
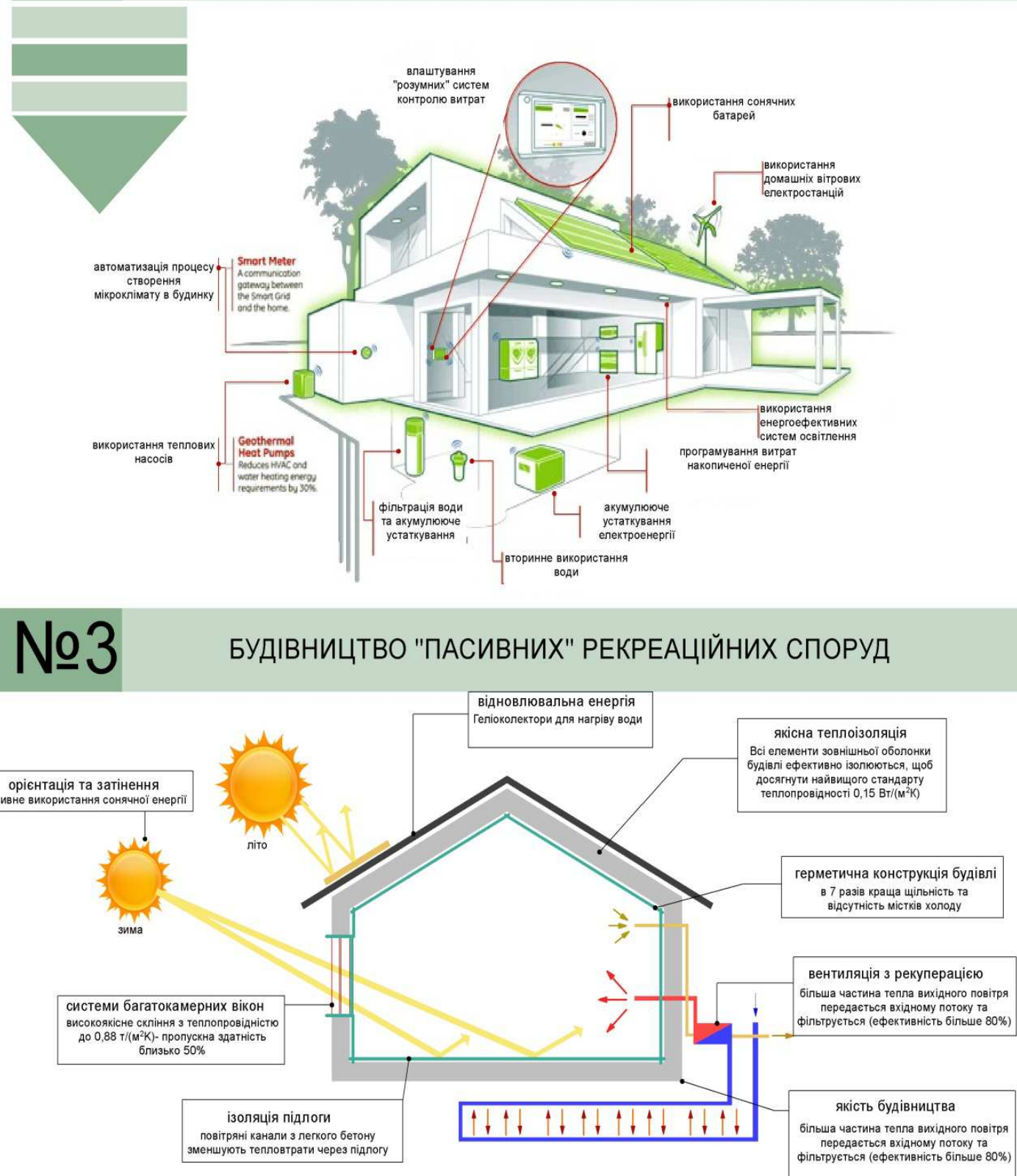

Рис. 4. Схема дії вимоги енергоефективності та екологічності проектованих об’єктів архітектури 
Слід формувати сміттєпереродні підприємства локального рівня, що забезпечуватимуть потреби кількох територіальних громад, а також на стадії генерального планування територій населених пунктів забезпечувати виділення зон будівництва цих об'єктів. Європейська практика демонструє рентабельність створення невеликих підприємств сміттєпереробки. Наприклад формування таких підприємств можливе на території передгірської частини Долинського, Богородчанського та Косівського районів. Пошук можливостей використання альтернативних джерел енергії в останнє десятиліття став не тільки ознакою стилю, але і необхідністю енергоефективного використання ресурсів. Відповідно змінюються і підходи до формування архітектурних рішень створення додаткових територій розташування сонячних батарей та теплових колекторів на етапі генерального планування.

Ця категорія технічних об'єктів перейшла 3 інженерної галузі в архітектурну. Пошук естетичних та композиційних рішень гармонійної організації інженерних елементів в архітектурному образі та розпланувальній схемі $є$ важливим аспектом архітектурно-планувального вирішення об’єкта сучасної рекреації. Також вимога екологічності передбачає максимальне зменшення негативної дії процесу функціонування створених об'єктів рекреації на довкілля. Шляхом вирішення цієї проблеми $є$ створення генеральних планів забудови в межах розробленої стратегії, які б передбачали перспективи розвитку комплексу чи території 3 можливістю додаткового влаштування інженерних комунікацій. При цьому слід враховувати граничні можливості екосистеми рекреаційного ареалу та на початковому етапі створення концепції об'єкта сучасної рекреації розробити рішення максимального та поетапного втілення проекту.

Висновки. Сформовані вимоги сталого розвитку рекреації в гірських районах ІваноФранківської області мають широкий спектр застосування і охоплюють як макрозміни в системі створення містобудівної документації, так і процесу проектування об’ єктів архітектури загалом. Проте обгрунтовані вимоги мають узагальнювальний характер, а формування дієвого механізму розвитку рекреації потребує подальших уточнень та формування принципів і методичних рекомендацій на конкретних ділянках.

\section{Література}

1 Колесник В. Є. Оцінка ефективності реалізації природоохоронних заходів на вугільних шахтах [Текст] / В. С. Колесник, А. В. Павличенко // Вісник НТУ «ХПІ»: серія: Механікотехнологічні системи та комплекси. - Х. : НТУ «ХПІ», 2016. - № 50(1222). - С. 142-146.

2 Шмандій В. М. Теоретичні та практичні аспекти управління екологічною безпекою на основі антропоцентричного підходу [Текст] / В. М. Шмандій, О. В. Харламова // Вісник ХНУ ім. В.Н. Каразіна: серія «Екологія». - Х., 2013. - Вип. 9. - № 1070. - С. 24-30.

3 Gavrilidis A. A. Urban Landscape Quality Index - Planning Tool for Evaluating Urban Landscape sand Improving the Quality of Life [Text] / A. A. Gavrilidis, C. M. Ciocănea, M. R. Niţă, D. A. Onose // Procedia Environmental Sciences. - 2016. - № 32. - P. 155-167. - doi: 10.1016/j.proenv.2016.03.020.

4 Olga Bondarchuk. Ecological safety of visual environment and video ecological perception (vep) of Vinnitsa /Olga Bondarchuk, Vasyl Petruk// Environmental problems. - Lviv - 2016 - Vol.1 - No 1 P. 35-38.

5 Глух О. С. Оцінка якості візуального середовища деяких пам'яток архітектури м. Ужгорода / О. С. Глух // Науковий вісник Ужгородського університету. Серія : Хімія. - 2015. Вип. 2(34). - С. 95-97.

6 Фесюк В.О. Відеоекологічні особливості міст Північно-Західної України/В.О. Фесюк, М. М. Мельнійчук // Науковий вісник Волинського національного університету ім. Лесі Українки. - Луцьк: ВНУ ім. Лесі Українки. - 2009. - Т. № 4: Міжнародні відносини. - С. 220-226.

7 Milan Kumar Jana. Visual pollution can have a deep degrading effect onurban and suburban community: a study in few places of Bengal, India, with special reference toun organized billboards / Milan Kumar Jana, Tanaya De// European Scientific Journal June 2015 /Special/ edition ISSN\$ 18577881 (Print) e - ISSN 1857-7431 - P.1-14.

8 Кундельська Т. В. Огляд методик оцінки візуальних впливів в межах урбосистеми та пропозиції щодо проведення такої оцінки на території м. Івано-Франківська / Т. В. Кундельська // Екологічна безпека та збалансоване ресурсокористування. - 2017. - № 2. - С. 86-91. - Режим доступу: http://nbuv.gov.ua/UJRN/ebzp_2017_2_13. 
9 O. M. Mandryk, L. M. Arkhypova, O. V. Pobigun, O. R. Maniuk. Renewable energy sources for sustainable tourism in the Carpathian region// IOP Publishing. IOP Conf. Series: Materials Science and Engineering 144 (2016) 012007. Volume 144. - August 2016. International databases Web of science (Scopus) http://iopscience.iop.org/issue/1757-899X/144/1.

10 Renewable Energy Resources. John Twidell, Tony Weir. Taylor\&FrancisLtd. ROUTLEDGE: London, United Kingdom. - 2015. - 816 pages.

11 Renewable Energy: Powerfor a Sustainable Future/ Editedby Godfrey Boyle. Oxford, United Kingdom. - 2012, 584 pages.

12 Adam James. Fact Sheet: 6 Things You Should Know About The Value Of Renewable Energy [Elektronnijresurs]. - 2015 - Rezhim dostupu: http://thinkprogress.org.

\author{
I. Smadych \\ Ivano-Frankivsk National Technical \\ University of Oil and Gas
}

\title{
SUBMISSION OF REQUIREMENT FOR THE RECONCILIATION DEVELOPMENT IN THE MOUNTAINOUS REGION OF IVANO-FRANKIVSK OBLAST IN THE CONTEXT OF ENVIRONMENTAL SAFETY
}

Since 2000 the recreational infrastructure in the Carpathian region has been affected by a number of changes in the socio-economic, political, demographic, geopolitical and other spheres. They set new requirements for the creation of modern recreational facilities. The primary task in the recreational development of the mountainous areas in Ivano-Frankivsk oblast is to take into account the environmental requirements as a basic element of environmental conservation for the development of recreation.

In the previous studies, the analysis and evaluation of the potential of unused recreational resources of the region was carried out and the peculiarities and factors affecting the architectural and planning organization were described. Factors affecting the development of the recreational sphere are divided into five groups: social; economic; demographic; political; ecological; those relating to the material and spiritual culture of the population.

The author substantiates the following requirements for the environmental safety of recreational development in the mountainous regions of Ivano-Frankivsk oblast, namely: the requirement for compliance with regional development strategies and plans, which provides for the consideration and coordination of the strategies and programs for preserving the high level of environmental safety at all levels of recreational zoning and design; improving the scientific feasibility of design decisions with account of the environmental monitoring data and social orientation of architectural decisions in the formation of recreational environment that involves changing the system of public discussions and work with territorial communities, energy efficiency and environmental friendliness of the designed objects, which provides for the use of alternative energy sources, energy saving materials and designs as well as the environmental safety of design solutions.

Keywords: environmental safety of the region, recreational facilities, mountainous settlements of Ivano-Frankivsk oblast, requirements for recreational development.

\section{References}

1 Kolesnyk V. Ye. Otsinka efektyvnosti realizatsii pryrodookhoronnykh zakhodiv na vuhilnykh shakhtakh [Tekst] / V. Ye. Kolesnyk, A. V. Pavlychenko // Visnyk NTU «KhPI»: seriia: Mekhanikotekhnolohichni systemy ta kompleksy. - Kh.: NTU «KhPI», 2016. - № 50(1222). - S. 142-146.

2 Shmandii V. M. Teoretychni ta praktychni aspekty upravlinnia ekolohichnoiu bezpekoiu na osnovi antropotsentrychnoho pidkhodu [Tekst] / V. M. Shmandii, O. V. Kharlamova // Visnyk KhNU im. V.N. Karazina: seriia «Ekolohiia». - Kh., 2013. - Vyp. 9. - № 1070. - S. 24-30.

3 Gavrilidis A. A. Urban Landscape Quality Index - Planning Tool for Evaluating Urban Landscape sand Improving the Quality of Life [Text] / A. A. Gavrilidis, C. M. Ciocănea, M. R. Niţă, D. A. Onose // Procedia Environmental Sciences. - 2016. - № 32. - P. 155-167. - doi: 10.1016/j.proenv.2016.03.020. 
4 Olga Bondarchuk. Ecological safety of visual environment and video ecological perception (vep) of Vinnitsa /Olga Bondarchuk, Vasyl Petruk// Environmental problems. - Lviv - 2016 - Vol.1 - No 1 P.35-38.

5 Hlukh O. S. Otsinka yakosti vizualnoho seredovyshcha deiakykh pam'iatok arkhitektury m. Uzhhoroda / O. S. Hlukh // Naukovyi visnyk Uzhhorodskoho universytetu. Seriia : Khimiia. - 2015. Vyp. 2(34). - S. 95-97.

6 Fesiuk V.O. Videoekolohichni osoblyvosti mist Pivnichno-Zakhidnoi Ukrainy / V.O. Fesiuk, M. M. Melniichuk // Naukovyi visnyk Volynskoho natsionalnoho universytetu im. Lesi Ukrainky. Lutsk: VNU im. Lesi Ukrainky. - 2009. - t.№ 4: Mizhnarodni vidnosyny. - S.220-226.

7 Milan Kumar Jana. Visual pollution can have a deep degrading effect onurban and suburban community: a study in few places of Bengal, India, with special reference toun organized billboards / Milan Kumar Jana, Tanaya De// European Scientific Journal June 2015 /Special/ edition ISSN\$ 18577881 (Print) e - ISSN 1857-7431 - P.1-14.

8 Kundelska T. V. Ohliad metodyk otsinky vizualnykh vplyviv v mezhakh urbosystemy ta propozytsii shchodo provedennia takoi otsinky na terytorii m. Ivano-Frankivska / T. V. Kundelska // Ekolohichna bezpeka ta zbalansovane resursokorystuvannia. - 2017. - № 2. - S. 86-91. - Rezhym dostupu: http://nbuv.gov.ua/UJRN/ebzp_2017_2_13.

9 O. M. Mandryk, L. M. Arkhypova, O. V. Pobigun, O. R. Maniuk. Renewable energy sources for sustainable tourism in the Carpathian region// IOP Publishing. IOP Conf. Series: Materials Science and Engineering 144 (2016) 012007. Volume 144. - August 2016. International databases Web of science (Scopus) http://iopscience.iop.org/issue/1757-899X/144/1.

10 Renewable Energy Resources. John Twidell, Tony Weir. Taylor\&FrancisLtd. ROUTLEDGE: London, United Kingdom. - 2015. - 816 pages.

11 Renewable Energy: Powerfor a Sustainable Future/ Editedby Godfrey Boyle. Oxford, United Kingdom. - 2012, 584 pages.

12 Adam James. Fact Sheet: 6 Things You Should Know About The Value Of Renewable Energy [Elektronnijresurs]. - 2015 - Rezhim dostupu: http://thinkprogress.org.

Надійшла до редакиії 9 квітня 2019 р. 